\title{
Sikap Etis Dokter pada Pasien yang "Mendiagnosis" Diri Sendiri Menggunakan Informasi Internet pada Era Cyber Medicine
}

\author{
Frans Santosa $^{\mathrm{I}, 2}$, Agus Purwadianto ${ }^{\mathrm{I}, 3}$, Prijo Sidipratomo ${ }^{\mathrm{I}, 2}$, Peter Pratama, Pukovisa Prawiroharjo ${ }^{\mathrm{I}, 4}$ \\ ${ }^{\mathrm{I}}$ Majelis Kehormatan Etik Kedokteran Pengurus Besar Ikatan Dokter Indonesia \\ ${ }^{2}$ Fakultas Kedokteran Universitas Pembangunan Nasional Veteran Jakarta \\ ${ }^{3}$ Departemen Ilmu Kedokteran Forensik dan Medikolegal, Fakultas Kedokteran Universitas Indonesia/Rumah Sakit Cipto Mangunkusumo \\ ${ }^{4}$ Departemen Neurologi, Fakultas Kedokteran Universitas Indonesia/Rumah Sakit Cipto Mangunkusumo, Jakarta
}

\author{
Kata Kunci \\ Cybermedicine, diagnosis, internet \\ Korespondensi \\ pukovisa@ui.ac.id \\ Publikasi \\ (C) $2018 \mathrm{JEKI} /$ ilmiah.id \\ DOI \\ I0.26880/jeki.v2i2.16 \\ Tanggal masuk: 3I Maret 2018 \\ Tanggal ditelaah: 6 Mei 2018 \\ Tanggal diterima: 10 Mei 2018 \\ Tanggal publikasi: 12 Juni 2018
}

\begin{abstract}
Abstrak Saat ini, internet telah banyak menyajikan informasi tentang kedokteran dan kesehatan. Di satu sisi informasi yang tersaji berupa penemuan-penemuan baru dan keberhasilan ilmu kedokteran di bidang eksperimen, operatif, invasif, maupun konservatif, yang sangat berguna bagi dokter dalam menjalankan profesinya untuk menolong pasien dan membantu edukasi awam kepada pasien. Namun di sisi lain, informasi ini tidak dapat dipilih dan dipilah dengan baik oleh awam sehingga salah satunya melahirkan banyaknya pasien yang berusaha "mendiagnosis" dirinya sendiri, bahkan menterapi dirinya sendiri. Jenis pasien demikian semakin banyak, dan di tengah usaha coba-coba mereka mendiagnosis dan menterapi diri sendiri, mereka pergi ke dokter untuk meminta obat sebagaimana yang ia baca di internet untuk diresepkan atau bahkan lebih jauh lagi, dapat menyanggah diagnosis dan pendapat profesional dokter yang menangani. Diperlukan sikap etis dokter untuk dapat menghargai pasien sekaligus meluruskan dengan terang dan tegas terhadap informasi keliru yang dipercaya pasien.
\end{abstract}

\begin{abstract}
Nowadays, the internet has broadcasted various information about medicine and health. The information may be of new discoveries and success in the field of experiments, operative, invasive, and conservative, all of which is very useful for doctors in carrying out his duties to help and educate patients. But on the other hand, the community cannot determine the correctness of such information well, resulting in patients trying to "diagnose" himself, even self-medicating. There are increasing number of such patients, and during their attempt to diagnose and self-medicate, they go to doctors asking for drugs they read on the internet for prescription, or even further, to debate a professional doctor's diagnosis and opinion. Doctor's ethical attitude is required to honor such patient as well as to firmly straighten out the truth against such false information which the patient believes on.
\end{abstract}

\section{PENDAHULUAN}

Saat ini, nyaris semua orang di seluruh dunia saat ini telah menggunakan dan memanfaatkan teknologi informasi khususnya internet. Informasi-informasi tersebut dapat meliputi segala bidang, termasuk politik, ekonomi/perdagangan, budaya, sosial, teknologi, olahraga, dan juga kedokteran/ medis.

Mencari informasi medis dulu adalah sulit bahkan bagi seorang dokter. Publikasi jurnal kedokteran hanya dapat ditemukan di perpustakaan, dan bahkan kadang harus melalui proses pemesanan selama 5-7 hari. Namun, masamasa sulit tersebut telah berakhir sekitar tahun 1990-an dengan munculnya publikasi-publikasi baru yang dapat diunduh dari internet. Ilmu 
pengetahuan yang mengaplikasikan teknologi internet pada bidang kedokteran dan kesehatan masyarakat, bersama dengan studi mengenai dampak dan implikasi internet, serta evaluasi kesempatan dan tantangan dalam pelayanan kesehatan diisitilahkan sebagai cybermedicine (kedokteran internet).

Perlu diperhatikan bahwa cybermedicine berbeda dari telemedicine (kedokteran jarak jauh) walaupun keduanya berhubungan erat dengan teknologi internet, di mana cybermedicine digunakan untuk menyebarkan informasi klinis dan non-klinis kepada dunia umum, sementara telemedicine membagikan informasi klinis dalam lingkungan medis yang tertutup. ${ }^{1}$

Paralel dengan bioteknologi, cybermedicine berpotensi mengubah dunia dengan menghasilkan keuntungan yang beragam kepada manusia. Apalagi, informasi kedokteran dari internet adalah salah satu yang mendapatkan perhatian terbesar untuk dibaca dan bahkan diyakini sebagai kebenaran, karena umumnya mengklaim bahwa manusia akan hidup lebih lama dan lebih sehat. Sebut saja informasi mengenai penemuan-penemuan baru dan keberhasilan ilmu kedokteran di bidang eksperimen, operatif, invasif, maupun konservatif, yang sangat berguna bagi dokter dalam menjalankan profesinya untuk menolong pasien dan membantu edukasi awam kepada pasien.

Sebagaimana informasi lainnya yang tersebar di internet, tanggung jawab medis dan etik juga melekat pada informasi dalam cybermedicine, dalam hal ini terutama adalah etik kedokteran. Sayangnya ada oknum yang menyalahgunakan kemudahan tersebut untuk tujuan pribadi atau kelompoknya. Lalu lintas informasi di dunia internet tersebut sedemikian masif dan membanjir, bercampur baur antara informasi yang otentik, nyata, serta berguna, dan yang keliru, bohong, serta menyesatkan (hoax).

Bagi seorang dokter yang gemar membaca jurnal dan sumber informasi ilmiah kedokteran yang mutakhir, umumnya akan lebih mudah dalam memilah dan memilih mana informasi medis yang otentik dan mana yang keliru. Namun keahlian ini tidak dimiliki oleh pasien dan masyarakat awam, yang relatif tidak pernah belajar khusus ilmu-ilmu kedokteran mulai dari tingkat dasar hingga penerapan.

Akibatnya, pasien cenderung menganggap bahwa seluruh informasi medis yang tertulis di internet adalah nyata dan benar, bahkan jika tulisan itu dinarasikan dengan sangat meyakinkan, tulisan internet tersebut dianggap lebih benar daripada pendapat dokter sungguhan. Dari kepercayaan pasien terhadap informasi tersebut, mulailah ia "mendiagnosis" dirinya dengan data-data keluhan yang ia rasakan, dan bahkan mengobati dirinya dengan obat yang tertulis di internet. Masalah kemudian muncul ketika obat tersebut sulit didapatkan di apotek karena harus melalui resep dokter. Pasien yang sudah kadung yakin ini dapat tidak hilang akal dan menyiasati dengan datang ke dokter sungguhan hanya untuk meminta resep yang dimaksud.

Dokter yang dikunjungi, mendengar cerita pasien ini, mungkin akan menemukan hal-hal yang tidak sesuai, diskrepansi antara gejala pasien dan diagnosis yang dibuatnya sendiri. Namun sering kali, ketika sang dokter menyatakan ketidaksetujuannya, malah pasiennya berbalik mendebat dia dengan ilmu pengetahuan seadanya dari "Dr. Internet" yang tidak didukung oleh dasar pemahaman atas fisiologi dan patofisiologi. Tidak jarang dokter tersebut kemudian membalas dengan nada emosi yang kurang pantas dan bahkan menyebabkan pelanggaran etika kedokteran. Lalu bagaimanakah sikap dokter yang semestinya dalam menghadapi pasien seperti ini?

Dokter harus menjadi benteng terdepan dalam menghadapi informasi dari internet yang merugikan pasien. ${ }^{2}$ Sebaliknya, dokter juga harus menghindarkan diri dari penggunaan media sosial yang tidak sesuai dengan prinsipprinsip luhur profesi, di antaranya malah menyebarkan hoax atau beriklan secara berlebihan. ${ }^{2,3}$ Penyalahgunaan cybermedicine berupa kesengajaan melakukan propaganda informasi keliru (hoax) dapat dihukum menurut Undang-Undang Nomor 11 Tahun 2008 tentang Informasi dan Transaksi Elektronik, yang kemudian diperbaharui/diperjelas dalam Undang-Undang Nomor 19 Tahun 2016. ${ }^{4}$ 
Tulisan ini ditujukan untuk membahas berbagai aspek etik yang berhubungan dengan cybermedicine, khususnya dalam lingkup pelaksanaannya di Indonesia, bersama dengan peraturan-peraturan yang mendampingi pelaksanaannya.

\section{HASIL DAN PEMBAHASAN}

\section{Diagnosis dari "Dr. Internet"}

Masih beberapa menit lamanya Dr. L duduk di kursi meja tulis sambil membayangkan peristiwa yang baru dialaminya: dia baru saja untuk pertama kalinya "mengusir" seorang pasien, bukan karena pasiennya berbuat kekerasan atau bertindak kasar. Pasiennya adalah seorang gentleman berusia lima puluhan tahun, berpakaian rapi, tampak terawat. Ia adalah spesialis piranti lunak dan direksi dari sebuah bank, yang dengan tenang dan ramah memulai pembicaraan dengan Dr. L. Pasien kemudian mengutarakan keluhan rasa ingin sering buang air kecil yang menekan di daerah pubis dengan disertai rasa sakit.

Ketika Dr. L memulai dengan anamnesis yang mengarah ke dugaan penyakitnya, pasien langsung mengambil tablet PC dari tasnya dan mengatakan bahwa semua masalah penyakit sudah jelas. "Oh baik, siapakah TS yang merujuk Anda ke tempat praktik saya?" kata Dr. L ingin tahu. "Tidak ada yang merujuk saya kemari, saya mempelajari dan menyelidiki keluhan yang saya alami dan rasakan di internet."

Kemudian sang pasien memberitakan ada 2 kesimpulan diagnosis penyakit terkait keluhan yang dideritanya. Pasien sendiri berpendapat bahwa dia menderita prostatitis bakterial dan hanya datang ke poliklinik Dr. L untuk meminta resep. "Anda meminta saya menulis resep obat, tanpa harus memeriksa Anda, hanya karena Anda telah mendapat diagnosa penyakit Anda dari internet?"

Dr. L merasakan bahwa dalam dirinya mulai timbul rasa amarah yang meluap, tetapi jiwa profesionalisme tetap dipegang teguh, dan sebagai dokter dia harus dapat mengekang amarahnya dan mengatasi situasi ini demi sang pasien. "Tidak mungkin," jawab Dr. L datar. "Saya hanya menuliskan resep yang dibutuhkan oleh orang-orang yang secara sukarela mau menjadi pasien saya." Kemudian Dr. L mengakhiri pembicaraannya dengan sang pasien, yang segera meninggalkan poliklinik.

Contoh kasus di atas merupakan salah satu konsekuensi dari cybermedicine. Informasi medis yang terbuka untuk umum memungkinkan pasien untuk mempelajari sendiri penyakitnya, bahkan mendiagnosis diri sendiri. Tidak jarang muncul pasien yang lebih menguasai penyakitnya dibandingkan dokter yang dikunjunginya, dan dalam kasus demikian sering kali dokter merasa "dilangkahi” atau "direndahkan," sehingga sulit untuk mengontrol amarahnya.

\section{Sikap Dokter terhadap Pasien dari "Dr. Internet"}

Sebagai seorang profesional yang memiliki kompetensi terbaik dalam bidang kesehatan, dokter perlu tetap mengedepankan prinsipprinsip luhur yang terkandung dalam Sumpah Dokter dan KODEKI dalam menghadapi pasien yang mendiagnosis dirinya sendiri dengan informasi dari internet. Pasal 14 KODEKI berbunyi, "Seorang dokter wajib bersikap tulus ikhlas dan mempergunakan seluruh keilmuan dan keterampilannya untuk kepentingan pasien.... 5 Oleh karena itu, sikap seorang dokter dalam kasus seperti di atas sebaiknya adalah bijaksana dan tenang, karena tujuan mulia dari profesinya adalah demi kepentingan pasien, bukan demi harga dirinya apalagi amarahnya semata.

Dokterjugaharustetap mempertimbangkan muatan sumpah kedokteran, terutama sumpah kedokteran terbaru yang dirilis WMA yang lebih menegaskan salah satu frase sumpah "I WILL RESPECT the autonomy and dignity of my patient". ${ }^{8}$ Jangan sampai ketidaksukaan dan ketidaksetujuan kita sebagai dokter terhadap pasien yang telah memiliki banyak prasangka akibat membaca-baca sumber dari internet, membuat berkurang sikap kita untuk menghormati pasien tersebut.

Selain itu, hubungan luhur profesi dokter dengan pasien adalah sangat spesial, bukanlah seperti penyelenggara jasa biasa dengan kliennya, apalagi seperti atasan dengan bawahan. Dokter adalah mitra pasien dalam mencapai kesehatan 
dan hubungan dokter-pasien didasarkan pada kepercayaan penuh. Perbedaannya hanyalah dokter dibekali dengan berbagai ilmu dan pengalaman akan dunia medis, yang harus dibagikan kepada pasien. Namun, dokter yang mempelajari sedemikian banyak penyakit kadang tidak sepenuhnya mengetahui hal-hal detail, apalagi yang non-esensial, dari suatu penyakit. Apalagi pasien, yang berasal dari latar belakang keilmuan yang berbeda, tidaklah mungkin sepenuhnya memahami suatu penyakit sedetail apa pun artikel yang dibacanya, itu pun bila artikel tersebut adalah artikel berkualitas yang berbasiskan bukti. Logika dan penalaran medis adalah sesuatu yang harus dipelajari secara khusus selama bertahun-tahun serta ditempa oleh pengalaman dalam periode yang lebih lama lagi, sehingga tidak mungkin dikuasai hanya dari membaca selama beberapa menit. Hal demikian berlaku sebaliknya; tidaklah mungkin seorang dokter mampu menguasai penuh kemampuan pasiennya yang adalah spesialis piranti lunak, misalnya, hanya dengan membaca artikel tertentu selama beberapa menit. Diskrepansi pengetahuan antara dokter dan pasiennya ini harus diakui oleh kedua belah pihak dengan hati besar dan pikiran yang terbuka.

Komunikasi adalah kunci dalam kasus seperti ini. Pasien yang hanya membaca satu penyakit mungkin mengetahui beberapa fakta tambahan yang tidak diketahui sang dokter. Oleh karena itu, solusi terbaik adalah diskusi. Dokter dapat menanyakan apa yang diketahui pasien dari penyakitnya termasuk sumber artikel yang dibacanya. Dokter dengan dasar keilmuannya dapat membantu menilai apakah sumber artikel tersebut adalah valid secara medis atau hanya hoax. Terlepas dari apakah pasien tersebut memilih untuk memercayai penjelasan dari dokter ataupun tidak, semua dikembalikan pada prinsip otonomi pasien.

Kemudian, dokter dapat menawarkan pemeriksaan ulang untuk mengkonfirmasi diagnosis. Pasien perlu diberi pengertian bahwa tentunya diagnosis "Dr. Internet" hanya berdasarkan keluhan pasien ("anamnesis" yang tidak sistematis) tanpa disertai pemeriksaan fisik. Dalam pemeriksaan ulang tersebut sangat mungkin ditemukan gejala dan manifestasi klinis lain yang dapat mengarahkan ke diagnosis yang berbeda.

Bila pasien tetap menolak diperiksa dan dikaji ulang, sesungguhnya itu adalah termasuk hak pasien berdasarkan penjelasan cakupan pasal 10 KODEKI, butir ke-2 dan ke-4. ${ }^{5}$ Maka seyogyanya dokter wajib menghormati pendapat atau anggapan pasien atas penjelasannya, dan menyampaikan bahwa dengan demikian pasien menolak pelayanan medisnya yang merupakan satu kesatuan dari anamnesis, pemeriksaan fisik, pemeriksaan penunjang, hingga terapi.

Dokter juga perlu berkonsultasi kepada pakar etik kedokteran serta memahami konteks dan hal-hal apa saja yang diperlukan agar masalah ini kemudian tidak menjadi perkara kemahkamahan etik kedokteran di masa mendatang. ${ }^{?}$

\section{KESIMPULAN}

Dokter harus memegang teguh Sumpah Dokter dan menggunakan kemudahan cybermedicinesecara proporsionaldan profesional. Dokter hendaknya tidak menyebarkan berita yang tidak berlandaskan kenyataan, apalagi yang nyata-nyata bohong. Dokter hendaknya dapat berkepala dingin dalam menghadapi pasien yang mendiagnosis dirinya sendiri melalui informasi cybermedicine. Dokter juga hendaknya selalu mengedepankan kesejawatan dan bersatu bersama dalam menjaga kedamaian di NKRI melalui tulisan-tulisan yang konstruktif di bidang ilmu kedokteran.

\section{KONFLIK KEPENTINGAN}

Tidak ada konflik kepentingan.

\section{UCAPAN TERIMA KASIH}

Penulis memberikan ucapan terima kasih kepada Fadlika Harinda yang telah membantu penulis dalam merealisasikan tulisan ini. 


\section{REFERENSI}

1. EysenbachG,SaER,DiepgenTL.Shopping around the internet today and tomorrow: Towards the millennium of cybermedicine. BMJ. 1999 Nov 13;319(7220):1294-1294. https://doi.org/10.1136/bmj.319.7220.1294.

2. Prawiroharjo P, Librianty N. Tinjauan Etika Penggunaan Media Sosial oleh Dokter. J Etik Ked Ind. 2017 Oct 11;1(1):31. https://doi. org/10.26880/jeki.v1i1.7.

3. Prawiroharjo P, Meilia PDI. Dokter beriklan: Sebuah tinjauan menurut Kode Etik Kedokteran Indonesia (KODEKI) tahun 2012. J Etik Ked Ind. 2017 Oct 11;1(1):13. https://doi. org/10.26880/jeki.v1i1.4.

4. Undang-Undang Republik Indonesia nomor 19 tahun 2016 tentang perubahan atas Undang-Undang Republik Indonesia nomor 11 Tahun 2008 tentang informasi dan transaksi elektronik. 2016.

5. Majelis Kehormatan Etik Kedokteran Indonesia. Kode etik kedokteran tahun 2012. Jakarta; 2012.

6. Purwadianto A, Wasisto B, Sjamsuhidajat R. Penerapan revisi sumpah dokter terbaru oleh World Medical Association (WMA) di Indonesia. J Etik Ked Ind. 2018 Mar 19;2(1):7. https://doi.org/10.26880/jeki.v2i1.9.

7. Rozaliyani A, Meilia PDI, Librianty N. Prinsip penetapan sanksi bagi pelanggaran etik kedokteran. J Etik Ked Ind. 2018 Mar 19;2(1):19. https://doi.org/10.26880/jeki.v2i1.11. 

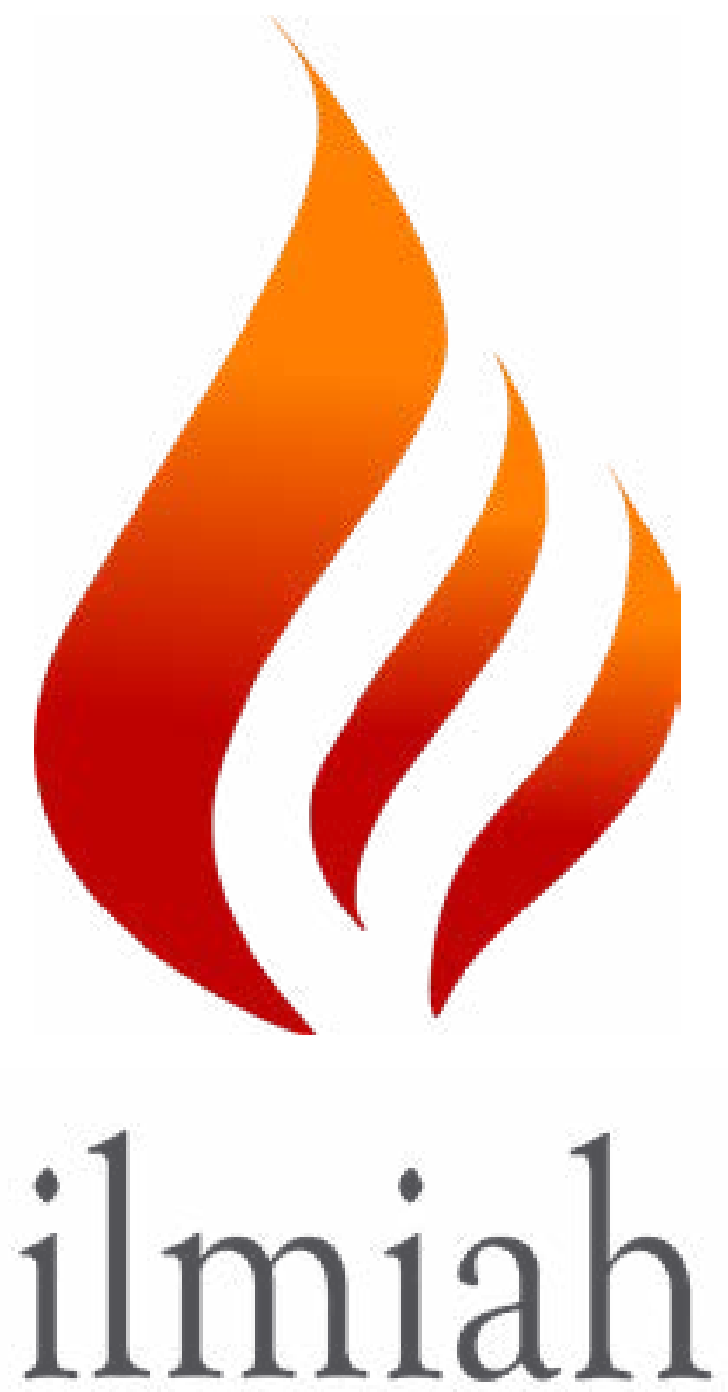

http://www.ilmiah.id your journal portal 